\title{
ANALISIS TUNGGAKAN PAJAK KENDARAAN BERMOTOR TERHADAP PAJAK DAERAH PADA DINAS PENDAPATAN DAERAH UPT KOTA KUPANG
}

\author{
Oleh :
}

\author{
Onesivorus Mira Mangngi*., Deasy S. R. Ndaparoka **
}

\begin{abstract}
Abstrak
Dengan diberlakukannya UU No 22 Tahun 1999 tentang pemerintahan daerah, pasal 78 dengan tegas dinyatakan bahwa penyelenggaraan tugas pemerintah daerah dan Dewan Perwakilan Rakyat Daerah (DPRD), dibiayai dari dan atas beban Anggaran Pendapatan dan Belanja Daerah (APBD). Dari sumber-sumber Pendapatan Asli Daerah (PAD) (Pasal 79 UU No. 22 1999) maka salah satu sumber Pendapatan Asli Daerah (PAD) adalah Pajak Kendaraan Bermotor (PKB). Dari hasil penelitian ditemukan bahwa Tunggakan PKB sangat berpengaruh terhadap Pajak Daerah sehingga dengan sendirinya Pajak Daerah akan menurun, apabila tunggakan PKB tidak dapat ditagih. Hasil penelitian menunjukkan bahwa tuggakan PKB tahun 2012 sebesar Rp.522.716.865, tahun 2013 sebesar Rp.1.343.128.933, Realisasi Pajak Daerah pada tahun 2011 sebesar 109\%, tahun 2012 sebesar 98\%, dan tahun 2013 sebesar 95\%. Terlihat dalam presentase perhitungan analisis dan presentase trend perbandingan tahun maka tunggakan PKB sangat berpengaruh negatif terhadap Pajak Daerah.
\end{abstract} Kata Kunci : Tunggakan. Pajak Kendaraan Bermotor,Pajak Daerah, Dinas
Pendapatan Daerah

*) Onesivorus Mira Mangngi; Alumni Mahasiswa Program Studi Akuntansi Sektor Publik Politeknik Negeri Kupang.

**) Deasy S. R. Ndaparoka; Dosen Program Studi Akuntansi Sektor Publik Politeknik Negeri Kupang.

\section{PENDAHULUAN}

Dengan diberlakukannya UU No 22 Tahun 1999 tentang pemerintahan daerah, pasal 78 dengan tegas dinyatakan bahwa penyelenggaraan tugas pemerintah daerah dan Dewan Perwakilan Rakyat Daerah (DPRD), dibiayai dari dan atas beban Anggaran Pendapatan dan Belanja Daerah (APBD). Hal ini berarti, daerah harus lebih berinisiatif menggali sumber-sumber pendapatan yang ada di daerahnya. Dalam pasal 79 UU No. 22 tahun 1999 sumbersumber pendapatan daerah terdiri atas, Pendapatan asli daerah (PAD), dana perimbangan, pinjaman daerah, dan lainlain pendapatan asli daerah yang sah.

Dari sumber-sumber Pendapatan Asli Daerah (PAD) (Pasal 79 UU No. 22 1999) maka salah satu sumber Pendapatan Asli Daerah (PAD) yang memberikan retribusi terhadap pendapatan Asli Daerah pada Dinas Pendapatan Daerah Propinsi Nusa Tenggara Timur adalah pajak daerah, 


\section{Desember}

dimana salah satu komponen yang terkait didalamnya adalah Pajak Kendaraan Bermotor (PKB).

Didalam keputusan Menteri Dalam Negeri No.1 tahun 2000 perhitungan dasar pengenaan pajak kendaraan bermotor bahwa pajak kendaraan bermotor (PKB) adalah pajak yang dipungut atas kepemilikan dan atau penguasaan kendaraan bermotor. Dinas Pendapatan Daerah Propinsi Nusa Tenggara Timur yang spesialisasi tugasnya melaksanakan sebagian urusan rumah tangga daerah dalam bidang pendapatan daerah masih mengalami kendala dalam peningkatan pajak kendaraan bermotor terhadap Pajak Daerah.

Dengan demikian Dinas Pendapatan masih perlu memperhatikan besar atau kecilnya nilai kontribusi Pajak Kendaraan Bermotor (PKB), serta menentukan pula Perkembangan Nilai Pajak Daerah itu sendiri. Untuk mewujudkan hal tersebut maka tunggakan PKB pada Dinas Pendapatan Daerah UPT Kota Kupang terjadinya tunggakan PKB karena, tingkat kesadaran/pendidikan, pengetahuan dan sistem pembayaran pajak kendaraan bermotor mempunyai peluang terjadinya tunggakan pajak oleh sebab itu perlu mengadakan penelitian secara ilmiah.

Tabel 1.1

Data Perbandingan Target dan Realisasi Penerimaan Pajak Kendaraan Bermotor UPT Kota Kupang T.A 2009-2013

Daerah Propinsi Nusa Tenggara Timur

\begin{tabular}{|l|c|c|c|c|}
\hline Tahun & $\begin{array}{c}\text { Target PKB } \\
(\mathrm{Rp})\end{array}$ & $\begin{array}{c}\text { Realisaasi PKB } \\
(\mathrm{Rp})\end{array}$ & $\begin{array}{c}\text { Tunggakan } \\
(\mathrm{Rp})\end{array}$ & $\%$ \\
\hline 2011 & 18.022 .160 .950 & 19.600 .326 .345 & -1.578 .165 .395 & 109 \\
2012 & 22.692 .792 .665 & 22.170 .075 .800 & 522.716 .865 & 98 \\
2013 & 28.190 .803 .225 & 26.847 .674 .292 & 1.343 .128 .933 & 95 \\
& & & & \\
& & & & \\
& & & & \\
\hline
\end{tabular}

Sumber Data: Laporan Bulanan dari UPT Pemda Kota Kupang, 2014.

Adapun target PKB pada tahun 2011 adalah sebesar Rp. 18.022.160.950 dengan realisasinya sebesar Rp. 19.600.326.345, selanjutnya target PKB pada tahun 2012 adalah sebesar Rp. 22.692.792.665 dengan realisasinya Rp. 22.170.075.800, selanjutnya target PKB pada tahun 2013 adalah sebesar Rp. 28.190.803.225 dengan realisasinya Rp.26.847.674.292.

Hal ini menunjukan pada tahun 2012-2013 terjadi tunggakan. Salah satu tindakan yang dilakukan oleh pihak petugas pajak yang berkerjasama dengan pihak kepolisian untuk mengurangi tunggakan $\mathrm{PKB}$ bermotor yang telah melunasi PKB nya dan bagi para pemilik kendaraan bermotor yang belum melunasi PKB nya akan dikenakan sanksi dalam Perda Nomor 1 Tahun 2002 yang 


\section{Desember}

sementara ini berlaku adalah wajib pajak yang tidak memenuhi kewajiban membayar pajak kendaraan bermotor dikenakan sanksi kenaikan sebesar 5\% (lima persen) dari pokok pajak untuk setiap keterlambatan untuk selama-lamanya 12 (dua belas) bulan. Berdasarkan uraian diatas, maka penulis tertarik mengadakan penelitian dengan judul "ANALISIS

TUNGGAKAN

PAJAK

KENDARAAN

BERMOTOR TERHADAP PAJAK DAERAH PADA DINAS PENDAPATAN DAERAH UPT KOTA KUPANG',

\section{Rumusan Masalah}

Berdasarkan uraian latar belakang masalah yang telah dikemukan di atas, penulis merumuskan masalah yang akan diteliti adalah sebagai berikut: "Bagaimana proporsi tunggakan Pajak Kendaraan Bermotor terhadap Pajak Daerah pada Dinas Pendapatan Daerah UPT Kota Kupang”.

Tujuan Penelitian

1. Untuk mengetahui proporsi tunggakan pajak kendaraan bermotor.

2. Untuk mengetahui besarnya Pajak Daerah

3. Untuk mengetahui proporsi tunggakan pajak terhadap Pajak Daerah

\section{Kerangka Berpikir dan Hipotesis}

Untuk mencapai hasil penelitian yang baik dibutuhkan dasar berpikir yang rasional, dalam upaya meningkatkan, melanjutkan dan memelihara sektor pembangunan yang sedang dilaksanakan secara terencana dan berkelanjutan rnutlak diperlukan dana yang cukup memadai untuk tetap dapat mempertahankan lajunya pembangunan secara konsisten dan berkesinambungan.

Upaya untuk mendapatkan sejumlah dana yang memadai perlu suatu upaya yang dilakukan secara terus menerus dengan menggaili dan manfaatkan berbagai peluang dari sumber dana atau potensi yang telah ada. Dalam usaha menyelenggarakan fungsi sebagai daerah otonomi, Dinas Pendapatan Daerah UPT Kota Kupang berupaya meningkatkan PAD salah satunya adalah pos penerimaan pajak daerah yaitu Pajak Kendaraan Bermotor.

Dinas Pendapatan Daerah Propinsi NTT yang spesialisasi tugasnya melaksanakan urusan rumah tangga daerah dalam bidang pendapatan daerah, dimana perkembangan Pendapatan Asli Daerah sangat dipengaruhi oleh tunggakan Pajak Kendaraan Bermotor. Dari uraian tentang pemikiran diatas, maka dapat ditransformasikan kedalam suatu skema kerangka berpikir sebagai berikut: 


\section{Desember}

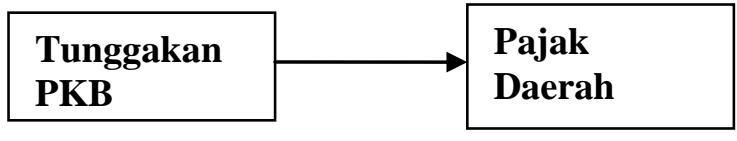

Gambar. 1 Kerangka Berpikir

Hipotesis

Hipotesis merupakan jawaban sementara terhadap rumusan masalah penelitian. Berdasarkan landasan teori dan kerangka berpikir di atas, hipotesis penelitiannya adalah "Jika tunggakan PKB dapat ditagih dengan maksimal maka akan meningkatkan Pajak daerah, sebaliknya jika Tunggakan PKB tidak dapat ditagih dengan maksimal maka akan mengurangi Pajak Daerah”

\section{METODE PENELITIAN}

Yang menjadi objek dalam penelitian ini adalah yaitu Tunggakan Pajak Kendaraan Bermotor terhadap Pajak Daerah pada Dinas Pendapatan Dearah UPT Kota Kupang. Jenis data yang digunakan dalam penelitian ini adalah: data kualitatif dan data kuantitatif.Sumber data yang digunakan dalam penelitian adalah: data primer dan data sekunder. Teknik yang digunakan dalam menganalisis data adalah bersifat deskriptif kuantitatif, yaitu penulis menganalisis data dengan menggunakan analisis trend dan perbandingan tahun untuk melakukan perbandingan tunggakan Pajak Kendaraan Bermotor dan Pendapatan Asli Daerah dalam memperoleh keuntungan sesuai dengan target yang telah ditentukan.

\section{HASIL PENELITIAN DAN PEMBAHASANHASIL ANALISIS DAN PEMBAHASAN}

Pajak Propinsi khususnya pajak kendaraan bermotor adalah merupakan salah satu penerimaan daerah, laba BUMD, penerimaan daerah lainnya dan penerimaan dinas setiap tahun anggaran. Jika hal ini diwujudkan pemerintah daerah tidak mengalami kesulitan dana untuk membiayai segala kegiatan rutin pembangunan.

Dengan demikian dapat dinyatakan bahwa sumber pendapatan daerah yang memberi kontribusi yang besar terhadap Pendapatan Asli Daerah adalah Pajak Daerah. Di mana salah satu komponen yang ada di dalamnya adalah Pajak Kendaraan Bermotor. Potensi Pajak Pajak Kendaraan Bermotor terhadap Pendapatan Asli Daerah sangat besar, tergantung bagaimana mengelola dana tersebut.

Data menunjukan terjadi tunggakan pada kendaraan bermotor karena adanya berbagai penyebab utama yaitu tingkat ekonomi, tingkat kesadaran/pendidikan dan sistem pembayaran PKB yang mempunyai peluang sehingga terjadinya Tunggakan Pajak Kendaraan Bermotor.

Hubungan antara objek kendaraan bermotor terhadap tunggakan pajak yang diperoleh cukup besar sehingga tidak memberikan kontribusi terhadap Pendapatan Asli Daerah. Untuk itu dapat 


\section{Desember}

dilihat pada tabel berikut:

Tabel 2

Tunggakan Objek PKB Tahun 20112013

\begin{tabular}{|l|c|c|c|}
\hline \multirow{2}{*}{$\begin{array}{l}\text { Tahun } \\
\text { Anggaran }\end{array}$} & \multicolumn{3}{|c|}{ Objek Kendaraan Bermotor } \\
\cline { 2 - 4 } & Target & Realisasi & $\begin{array}{c}\text { Objek yang } \\
\text { Menunggak }\end{array}$ \\
\hline 2011 & 78.645 & 67.792 & 10.853 \\
\hline 2012 & 90.620 & 73.977 & 16.643 \\
\hline 2013 & 96.733 & 83.273 & 13.460 \\
\hline
\end{tabular}

Sumber: UPT Kota Kupang, 2014

Objek yang menunggak $=$ target - realisasi

Hasil perhitungan menunjukkan bahwa objek PKB yang menunggak pada tahun 2011 sebanyak 10.853, pada tahun 2011 objek PKB yang menunggak sebanyak 16.643 dan pada tahun 2013 objek PKB yang menunggak sebanyak 13.460 .

Hal ini dikarenakan kurangnya kesadaran, pengertian, pemahaman para pemilik kendaraan bermotor untuk melaksanakan kewajibannya sebagai pemilik barang (Kendaraan Bermotor) yang harus taat pada peraturan yang berlaku,dan dilihat dalam kondisi ekonomi para pemilik kendaran bermotor yang mana pewajib pajak/orang yang ekonominya lemah,secara garis besar pengaturan manajemen rumah tangga yang kurang terakomodir baik maka terjadinya unsur kesengajaan untuk menghindarkan diri dari tanggung jawabnya sebagai pemilik kendaraan bermotor maka saat itu terjadinya tunggakkan PKB terhadap Pajak Daerah dan ada pula tunggakkan terjadi karena mengalami kecelakaan yang mana para nemilik kendaraan bermotor tidak ada warisan kepada keluarganya mempertanggung jawabkan kewajiban sebagai pemilik kendaraan bermotor sehingga terjadinya tunggakkan PKB terhadap Pajak Daerah.

Dengan demikian tunggakkan PKB juga terjadi karena berbagai masalah yang dialami oleh pemilik kendaraan bermotor seperti pencurian kendaraan bermotor dan pemalsuan dokumen kendaraan ataupun berbagai kejahatan dan pelanggaran di bidang kendaraan bermotor.

Analisis Pajak Daerah.

Pajak Daerah merupakan salah satu sumber keuangan daearah untuk membiayai kegiatan pemerintah dan pembangunan di daerah. Dalam penelitian ini yang dibahas adalah pengaruh tunggakan PKB yang besar yang tidak memberikan kontribusi pada penerimaan daerah. Untuk lebih jelasnya terlihat pada tabel berikut ini:

Tabel 3

Target dan Realisasi Pajak Daerah

Pada Dinas Pendapatan Daerah UPT Kota Kupang Tahun 2011-2013

\begin{tabular}{|l|l|l|l|c|}
\hline No & \multicolumn{1}{|c|}{$\begin{array}{c}\text { Tahun } \\
\text { Anggaran }\end{array}$} & $\begin{array}{c}\text { Target Pajak } \\
\text { Daerah }\end{array}$ & Realisasi PKB & $\%$ \\
\hline 1 & 2011 & 18.022 .160 .950 & 19.600 .326 .345 & 109 \\
\hline 2 & 2012 & 22.692 .792 .665 & 22.170 .075 .800 & 98 \\
\hline 3 & 2013 & 28.190 .803 .225 & 26.847 .674 .292 & 95 \\
\hline
\end{tabular}

Sumber : UPT Kota Kupang, 2014 


\section{Desember}

Dari tabel di atas dapat dijelaskan bahwa untuk tahun anggaran 2011 realisasi Pajak Daerah sebesar Rp.19.600.326.345 sedangkan target Pajak Daerah yang di tetapkan sebesar Rp.18.022.160.950 atau mencapai 109\%. Hal ini menunjukkan bahwa realisasi Pajak Daerah lebih tinggi dari target Pajak Daerah yang ditetapkan. Tahun anggaran 2012 target Pajak Daerah sebesar Rp.22.692.792.665, sedangkan realisasi Pajak Daerah mencapai Rp. 22.170.175.800 atau mencapai 98\%. Hal ini menunjukan bahwa realisasi PAD lebih rendah dari target Pajak Daerah yang ditetapkan. Selanjutnya realisasi Pajak Daerah untuk tahun anggaran tahun 2013 realisasi Pajak Daerah mencapai Rp. 26.847.674.292 sedangkan target Pajak Daerah sebesar Rp.28.190.803.225 atau mencapai 95\%. Hal ini juga menunjukan bahwa realisasi Pajak Daerah lebih rendah dari target Pajak Daerah yang ditentukan.

Dari data Pajak Daerah di atas menunjukkan bahwa tiga tahun yang ada mengalami penurunan hal ini disebabkan karena terjadinya tunggakan PKB yang diperoleh dari tahun ke tahun sangat meningkat sehingga menyebabkan Pajak Daerah cenderung menurun. Untuk mengetahui pengaruh tunggakan pajak kendaraan bermotor terhadap Pajak Daerah, maka berikut ini penulis akan menganalisis dengan metode analisis trend dan perbandingan tahun.

Tabel 4

Komponen Analisisi Trend

\begin{tabular}{|c|c|c|c|c|c|c|}
\hline $\begin{array}{c}\text { Tahun } \\
\text { Anggaran }\end{array}$ & Target Pajak Daerah & \multicolumn{2}{|c|}{ Realisasi Pajak Daerah } & Tunggakan PKB & \multicolumn{2}{|c|}{ Trend } \\
\hline & & Rp & $100 \%$ & Rp & $\begin{array}{c}\text { Ralisasi } \\
\text { Pajak } \\
\text { Daerah }\end{array}$ & $\begin{array}{c}\text { Tunggakan } \\
\text { PKB }\end{array}$ \\
\hline 2011 & 18.022 .160 .950 & 19.600 .326 .345 & 109 & -1.578 .165 .395 & $109 \%$ & - \\
\hline 2012 & 22.692 .792 .665 & 22.170 .075 .800 & 98 & 522.716 .865 & $98 \%$ & $10 \%$ \\
\hline 2014 & 28.190 .803 .225 & 26.847 .674 .292 & 95 & 1.343 .128 .933 & $95 \%$ & $9 \%$ \\
\hline
\end{tabular}

Sumber: UPT Kota Kupang, 2014

Tunggakan PKB $=\underline{\text { Ralisasi Pajak Daerah }} \times 100 \%$

Target Pajak Daerah

Berdasarkan hasil analisis maka realisasi Pajak Daerah dibagi target Pajak Daerah dikali dengan 100\% adalah: 


\section{Desember}

Tahun $\begin{aligned} 2012= & \frac{\text { Rp. } 22.170 .075 .800 \times 100 \%}{\text { RP.22.692.792.665 }} \\ & =10 \%\end{aligned}$

Tahun $2013=\underline{\text { Rp. } .26 .847 .674 .292 \times 100 \%}$

$$
\begin{aligned}
& \text { Rp.28.190.803.225 } \\
= & 9 \%
\end{aligned}
$$

Dengan demikian maka hasil perhitungan yang ada dapat diartikan sebagai berikut: dimana pada tahun 2012 prosentase perhitungan mencapai $10 \%$ dan pada tahun anggaran 2013 prosentase perhitungan mencapai 9\%. Sedangkan pada tahun 2011 tidak terdapat tunggakan. Dilihat tiga tahun terakhir ini prosentase perhitungan tunggakkan PKB naik turun, itu disebabkan karena semakin bertambahnya pemilik kendaraan dan kurangnya tingkat kesadaran masyarakat dalam membayar pajak kendaraaan bermotor semakin pula bertambah obyek yang menunggak PKB sehingga hasilnya mempengaruhi Pajak Daerah yang ada.

\section{PENUTUP}

\section{KESIMPULAN.}

Dari hasil uraian dan analisis masalah di atas maka penulis dapat menarik kesimpulan sebagai berikut:

1. Tunggakan PKB sangat berpengaruh terhadap Pajak Daerah sehingga dengan sendirinya Pajak Daerah akan menurun, apabila tunggakan PKB tidak dapat ditagih.

2. Hasil penelitian menunjukkan bahwa tuggakan PKB tahun 2012 sebesar Rp.522.716.865, tahun 2013 sebesar Rp.1.343.128.933, Realisasi Pajak Daerah pada tahun 2011 sebesar 109\%, tahun 2012 sebesar 98\%, dan tahun 2013 sebesar $95 \%$.

Terlihat dalam presentase perhitungan analisis dan presentase trend perbandingan tahun maka tunggakan $\mathrm{PKB}$ sangat berpengaruh negatif terhadap Pajak Daerah.

\section{SARAN}

Untuk melengkapi tulisan ini sebagai solusi atau pemecahan terhadap permasalahan yang ada, penulis berikan pula beberapa saran sebagai berikut:

1. Untuk meningkatkan pemungutan tunggakan $\mathrm{PKB}$ sehingga tercapainya target Pajak Daerah yang ditetapkan maka fungsi koordinasi dan pengawasan harus selalu diperhatikan dalam pelaksanaan tugas di lapangan dengan selalu melibatkan instansi terkait yaitu DISPENDA, LLAJ dan Dinas Kepolisian sehingga 
memungkinkan adanya umpan balik, kesamaan fisi dan persepsi dalam meningkatkan pemungutan tunggakan PKB sehingga tercapainya target Pajak Daerah yang ditetapkan,

2. Untuk mendukung upaya peningkatan Pajak Daerah dan dapat meningkatkan prestasi yang ada maka perlu adanya peningkatan kemampuan aparat sebagai pengelola Pendapatan Daerah perlu juga disesuaikan dengan

\section{DAFTAR PUSTAKA}

Andriani, P.J. 2000. Perpajakan Indonesia. Jakarta: UI Press. Jakarta.

Anwar, Khaeril. 2014. Analisis Kontribusi dan Potensi Pajak Kendaraan

\section{Bermotor}

Terhadap Pendapatan Asli Daerah Provinsi Sulawes Selatan.Skripsi,

Universitas Hasanuddin. Makasar.

Amilin dan Fanny Yusronillah. (2009). Analisis Pengaruh Tingkat Pendidikan Dan Jenis Pekerjaan Wajib Pajak Terhadap Motivasi Dalam Memenuhi Kewajiban Pajak.

Dinas Pendapatan Asli Daerah Provinsi NTT.1999 Himpunan Peraturan Daerah Mardiasmo. 2011. Perpajakan Edisi Revisi. Yogyakarta: CV Andi Offset.Yogyakarta. perkembangan keadaan, sehingga sistem pemungutan akan lebih berdaya guna dan berhasil serta terwujudnya peningkatan pelayanan kepada masyarakat serta Pendapatan Daerah di masa yang akan datang.

Perlu dibangun para wajib pajak untuk membayar pajak kendaraan bermotor tanpa harus menunggu peringatan dari DISPENDA Propinsi NTT dengan menghimbau melalui media massayang ada di NTT.

Dinas Pendapatan Asli Daerah Provinsi NTT.2002 Himpunan Peraturan Daerah

Djajadininggrat, S.J. 2003. Perpajakan

Teori dan Kasus. Jakarta: Salemba Empat. Jakarta

Kurniawan dan Bagas Pamungkas, 2006. Penagihan Pajak

Mudrajat Kuncoro. 2004. Metode Kuantitatif Teori dan Aplikasi untuk Bisnis dan Ekonomi

Munawir. 2004.Perpajakan. Penerbit: Liberty. Yogyakarta

Mardiasmo. 2002. Perpajakan. Yogyakarta: CV Andy Offset. Yogyakarta.

Mardiasmo. 2008. Perpajakan Edisi Revisi 2008. Yogyakarta: CV Andy Offset. Yogyakarta.

Siahaan, Marihot. 2005. Pajak Daerah dan Retribusi Daerah 